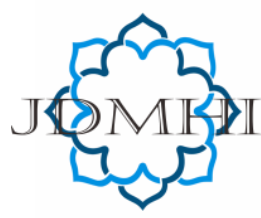

email: jdmhi@walisongo.ac.id

Journal of Digital Marketing and Halal Industry

ISSN: 2716-4810 (print) ISSN: 2716-4802 (online)

\title{
Islamic Entrepreneur Resilience Model: Retail Business Survives During Crisis
}

\author{
Rahman E1 Junusi, Ferry Khusnul Mubarok \\ Universitas Islam Negeri Walisongo Semarang, Indonesia
}

\section{A R T I C LE I N F O}

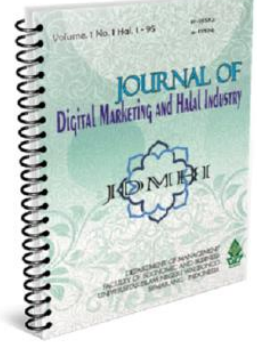

Article history:

Received 21 September 2020

Accepted 25 October 2020

Published 31 October 2020

Keywords:

Islamic Entrepreneur Resilience,

Retail Business, Customer

Orientation, Social Capacity,

Islamic Spiritual Digital

Marketing

\section{A B S T R A C T}

Covid-19 affects all sectors, including micro, small and medium enterprises. The purpose of this study is to determine the factors that affect the resilience of Muslim retail entrepreneurs and to develop models of entrepreneurial strength in the face of crises due to Covid 19. The research sample used 160 Muslim retail entrepreneurs who are members of the Sampoerna Retail Community (SRC). The analytical techniques used are factor analysis and SEM model testing with AMOS. From the results of the factor analysis, there are six variables, namely resilience capacity entrepreneurship, customer orientation, retailer's attitude, social capacity, Islamic Spirituality and digital marketing that affect the resilience of Muslim retail entrepreneurs. The model developed shows that social capital is not significant in explaining the resilience capacity of Muslim retail entrepreneurs. For that, we need encouragement, support, coaching and support to empower retail business businesses.

@2020 Journal of Digital Marketing and Halal Industry

\section{Introduction}

The COVID-19 pandemic outbreak is disrupting the global economy and spreading rapidly, obliging entrepreneurs to be resilient and innovative in developing alternative methods to create new opportunities in times of crisis (Dijk, 2020). Coronavirus shocks since January 2020, have had a broad impact in almost all sectors of the global economy, including world retail trade. For the United States, retail sales decreased by $9.1 \%$ or the equivalent of 321 billion USD. Asia Pacific experienced a decrease of about $10 \%$ or the equivalent of 767 billion USD. The decline in

\footnotetext{
* Corresponding author.email: rahman_eljunusi@walisongo.ac.id DOI: http://dx.doi.org/10.21580/jdmhi.2020.2.2.6350
} 
retail sales in China to minus 2.8 per cent or 192 billion USD. Singapore retail sales fell to minus $13.3 \%$.

Meanwhile, in Indonesia, based on a survey of Bank Indonesia, retail sales experienced a decline in sales, especially the clothing subgroup by minus $70.9 \%$ and the cultural and recreational goods group by minus $48.5 \%$. Thus, COVID-19 pandemic is this type of event, as (1) the impact remains largely unknown; (2) the crisis is still ongoing with no end in sight; and (3) its impact is increasingly devastating for human health and economic well-being, with an estimated global economic contraction of more than two people (Thorgren \& Williams, 2020). In facing the Covid 19 crisis, entrepreneurs must be challenging and innovative in creating new opportunities in facing difficulties such as this pandemic. Resilience is the ability to overcome adversity. It means "the capacity to maintain or regain, psychological well-being in the face of challenges, underlining that the ability to develop, develop and function effectively despite difficult circumstances or events" (Seligman, 2011). Meanwhile, according to Hayward et al. al., (2010) resilience as a positive adaptation to adversity, can be an essential ingredient for entrepreneurial success.

Muslim entrepreneurs always act according to Islamic values. In other words, Muslim entrepreneurs do not only invest for economic, social and environmental purposes but seek Allah's gifts (Machmud \& Hidayat, 2020). The behaviour of Muslim entrepreneurs in getting opportunities through optimization of resources based on the Islamic work ethic (Shamsudin et al.,
2010). Islamic work ethic is a personality attitude that gives birth to the belief that working is not only to glorify oneself but also as a form of good deeds. Thus, working based on the principle of faith, not only shows like a Muslim but makes him a trusted and trustworthy figure. In the direction, the doctrine in Islam is related to the ultimate goal of human life (Machmud \& Hidayat, 2020). In the last decade, research on entrepreneurial resilience has grown in importance, as people are more aware of the consequences of the crisis (Tukamuhabwa et al., 2015). Due to the speed of change in the economy, society and technology, for this reason, business resilience is significant in business survival (Dijk, 2020). By looking at these conditions, it is interesting to study how the resilience capacity of retailers in facing changing market conditions and consumer preferences. Then, how to reconfigure marketing skills, as well as behaviour in adapting to these changes. The ability to increase sales by playing a role in supporting the capacity for resilience to face the crisis due to Covid 19. Therefore, this study tries to describe the factors that influence the resilience capacity of Muslim retailers and how to model the resilience capacity of Muslim entrepreneurs in facing crises. The resilience model of Muslim entrepreneurs can produce strategies in dealing with an environment full of uncertainty.

\section{Literature Review}

\section{Entrepreneurial Resilience and Crisis}

According to Youssef \& Luthans, (2007; Luthans et al., (2006) resilience as a positive capacity "like state", which is more changeable 
than pure traits but remains more stable than psychological states, than personality traits. Besides, resilience can be defined as a protection mechanism that varies, depending on the situation and aspects of life that affect it (Rutter, 1987). Druss \& Douglas, (1988) conceptualizes resilience as individuals who face difficulties in optimism and positivity. So Thus, entrepreneurial resilience is the capacity of entrepreneurs who overcome adversity and create new opportunities. There is strong empirical support for entrepreneurial resilience capacity to affect firm performance (Dijk, 2020). Ayala \& Manzano, (2014) argue that successful entrepreneurs set business goals and make the right decisions in an uncertain environment. Whereas London, (1993) states that tough entrepreneurs are willing to work hard to achieve their goals, and adapt to changes to take advantage of new situations and can learn from their mistakes. It can be concluded that this definition entrepreneurial resilience can be divided into two components, where the first is the capacity to absorb strain, and the second is the capacity to recover from adversity and adjust positively (Carmeli et al., 2013).

In addition, Linnenluecke, (2017) succeeded in overcoming adverse events as an entrepreneur; resilience is needed. According to Akgün \& Keskin, (2014), more strength leads to better use of innovations which increase firm performance and are therefore very important in overcoming environmental upheavals and difficulties. According to Brück et al., (2011), the resilience of entrepreneurs underlies that "extreme events can foster new business", due to disrupted habits and traditional institutions weakening, which can lead to "changes in the balance of power in favour of smaller, more flexible organizations".
When faced with adversity, formidable entrepreneurs have to face the consequences and use their flexibility and innovation to turn discomfort into opportunities by creating new ideas. In the corporate context, the view of organizational resilience is "the ability of companies to effectively absorb, develop situation-specific responses, and ultimately engage in transformative activities to take advantage of shocks that could potentially threaten organizational survival" (LengnickHall et al., 2011). Organizational capacity for resilience is developed through strategic human resource management to create competencies among core employees, which, when aggregated at the corporate level, enables the organization to achieve the ability to respond in a resilient manner when they experience shock difficulties.

\section{Islamic Entrepreneur}

Muslim entrepreneurs are defined as entrepreneurs who always act following Islamic principles and values. In other words, he can be considered as a person who not only invests in making economic, social and environmental meanings but more than that in seeking gifts from Allah (Machmud \& Hidayat, 2020). The basic framework of entrepreneurship based on Islam or Muslimpreneur is taqwa (faith) and worship of Allah SWT (Machmud et al., 2018). Within this framework, other elements complement Islamic entrepreneurship, including the concept of halal, namely the idea of efficiency, noble values, honesty, welfare, knowledge, and concern for the community and the environment. The developed Islamic entrepreneurship cannot be separated from the foundation of tauhid which consists of the concepts of al-iman (belief), al-Ilm (knowledge) 
and al-Amal (pious behaviour and efforts) (S. A. C. Abdullah \& Sahad, 2016). The relationship between spiritual and business, according to Islamic teachings. Hoque et al. (2014) stated that "many Muslims still pay little or no attention to Islamic guidelines when developing and managing business enterprises". Overall, Islam encourages its adherents to become innovative and active entrepreneurs. Gümüsay, (2015) considers Islam to be an entrepreneurial religion because investment in knowledge in a society motivates its supporters to carry out entrepreneurial activities. Moreover, Omri et al., (2017) also found moderate Islamic work ethics in a positive relationship between creativity and entrepreneurial behaviour. They concluded that individuals with stronger Islamic beliefs were more likely to engage in creative skills and thus positively influence entrepreneurial behaviour.

\section{The Method, Data, and Analysis}

The sample used is Muslim entrepreneurs who are members of the Sampoerna Retail Community (SRC) Semarang City, which has approximately 500 members. Distribution of questionnaires through online, by distributing 250 questionnaires, 171 people have responded, 11 questionnaires are incomplete so that 160 questionnaires or 64 per cent of respondents can be further analyzed. The descriptions of respondents are described in Table I.

Table 1. Summary of Respondents Descriptions

\begin{tabular}{lrrlrr}
\hline Gender & $\mathrm{n}$ & $\%$ & Length of Business & & \\
Male & 64 & $40 \%$ & $<5$ years & 14 & $9 \%$ \\
Female & 96 & $60 \%$ & $3-6$ years & 32 & $20 \%$ \\
Age & & & $7-10$ years & 45 & $28 \%$ \\
$<30$ years & 8 & $5 \%$ & $>10$ years & $43 \%$ \\
$30-39$ years & 42 & $26 \%$ & & \\
$40-49$ years & 54 & $54 \%$ & & \\
$>49$ years & 23 & $14 \%$ & \\
\hline
\end{tabular}

Data analysis used: (1) to test the factors that influence Muslim resilience using factor analysis and to test the model of the resilience of Muslim entrepreneurs using structural modelling equations (SEM) through Analysis of Moment Structures (AMOS) software.

\section{Result and Discussion}

Factors Affecting the Resilience of Muslim Entrepreneurs
From various literary studies (Martinelli et al., 2019; Martinelli \& Tagliazucchi, 2019); Härting et al., 2019; Machmud \& Hidayat, 2020; Alves et al., 2020; Kuckertz et al., 2020; Branicki et al., 2018; Bhamra et al., 2011; Korber \& McNaughton, 2017; Bullough \& Renko, 2013; Ayala \& Manzano, 2014; Annalakshmi \& Abeer, 2011; Bojorges Moctezuma \& Rajagopal, 2016; Salleh et al., 2020) obtained the following factors and modified: My business can stand tall and can 
survive; My business is capable of identifying and solving problems; My company has managed to stay on the market even in crisis conditions; My business is quick to take action and flexible; My efforts are capable of generating opportunities even from a crisis; Generating opportunities even from unfavorable circumstances; Generating opportunities even from unfortunate events; I can quickly respond to changing customer requests; I provide products at affordable prices; I am able to adapt to change; I am able to adapt to change; I can handle whatever happens; I try to find the positive side of things; I was able to achieve my goals despite the obstacles; I stay focused even under pressure; I consider myself a healthy person facing difficulties; Suppliers / sales support my business; Customers are very supportive of my business; The Municipal Government supports my efforts; The merchant / retail association supports my business; Other traders / retailers support my business; Banks and financial institutions support businesses (Mubarok, 2019); Family, friends and acquaintances support my efforts; Businesses that run part of worship; I try to get blessings; I am always grateful for the gift of creation; I prioritize Spirituality in my place of business; I invest and submit; I use social media to help make business decisions; I use digital marketing to increase marketing and I use digital marketing to increase sales (Al-bantani, 2020). Principal component analysis with varimax rotation was performed on 30 items to determine whether these factors could be empirically verified. Factor analysis yielded six factors that can be interpreted as influencing entrepreneur resilience. The first factor is Social Capital which contains seven items. The second factor is the Resilience Capacity Entrepreneur which contains six items. The third factor is (Islamic spiritual) it has five items. The fourth factor is the Retailer's Individual Attitude, which includes six items. The fifth factor is Digital Marketing which contains three things while the sixth factor is Customer Orientation which includes three items.

Tabel II. Analisis faktor eksplorasi (N = 160)

\begin{tabular}{|c|c|c|c|c|c|c|c|}
\hline \multirow[b]{2}{*}{ No. } & \multirow[b]{2}{*}{ Item } & \multicolumn{6}{|c|}{ Factor } \\
\hline & & 1 & 2 & 3 & 4 & 5 & 6 \\
\hline $\mathrm{x} 1$ & My business can stand tall and can survive & .075 & .882 & .047 & .083 & .093 & .081 \\
\hline $\mathrm{x} 2$ & $\begin{array}{l}\text { My business is capable of identifying and solving } \\
\text { problems }\end{array}$ & .013 & .870 & .048 & .106 & .093 & .138 \\
\hline $\mathrm{x} 3$ & $\begin{array}{l}\text { My business has managed to stay on the market even } \\
\text { in crisis conditions }\end{array}$ & .026 & .882 & .069 & .079 & .042 & .032 \\
\hline $\mathrm{x} 4$ & My business is fast taking action and flexible & .079 & .786 & .176 & .117 & .155 & -.01 \\
\hline $\mathrm{x} 5$ & $\begin{array}{l}\text { My efforts were able to generate opportunities even } \\
\text { from a crisis situation }\end{array}$ & .112 & .723 & .096 & .203 & .133 & .155 \\
\hline x6 & $\begin{array}{l}\text { My efforts were able to generate opportunities even } \\
\text { from a crisis situation }\end{array}$ & .191 & .686 & .008 & .131 & .074 & .417 \\
\hline $\mathrm{x} 7$ & I often offer new products or services & .217 & .122 & .033 & .085 & -.04 & .794 \\
\hline $\mathrm{x} 8$ & I can respond quickly to changing customer requests & .197 & .185 & .065 & .143 &. .02 & .839 \\
\hline
\end{tabular}


$\mathrm{x} 9$ I provide products at affordable prices

$\mathrm{x} 10$ I can adapt to change

x11 I am able to handle whatever happens

$\mathrm{x} 12$ I try to find the positive side of things

$\mathrm{x} 13$ I was able to achieve my goals despite the obstacles

$\mathrm{x} 14$ I stay focused even under pressure

x15 I consider myself a strong person facing difficulties

x16 Suppliers / sales support my business

x17 Customers really support my business

x18 The Municipal Government supports my efforts

x19 The merchant / retail association supports my business

x20 Other traders / retailers support my business

$\mathrm{x} 21$ Banks and financial institutions support the business

x22 Family, friends and acquaintances support my endeavors

x23 Businesses that run part of worship

x24 I'm trying to get blessings

x25 I am always grateful for the gift of creation

$\mathrm{x} 26$ I prioritize spirituality in my place of business

x27 I invest and submit

x28 I use social media to help make business decisions

x29 I use digital marketing to increase marketing

x30 I use digital marketing to increase sales

\begin{tabular}{llllll}
.071 & .129 & .088 & -.02 & .158 & .776 \\
.128 & .112 & -.03 & .938 & .013 & .046 \\
.113 & .125 & -.04 & .969 & -.01 & .047 \\
.118 & .117 & -.05 & .967 & -.02 & .049 \\
.129 & .091 & .031 & .940 & -.01 & .042 \\
.158 & .484 & .060 & .586 & .148 & -.02 \\
.142 & .285 & .064 & .572 & .097 & .197 \\
.840 & .091 & .128 & .111 & .095 & .100 \\
.813 & .004 & .081 & .051 & .077 & .134 \\
.822 &. .00 & .131 & .134 & .139 & .155 \\
.748 & .078 & .141 & .044 &. .02 & .051 \\
.857 & .108 & .060 & .149 & .104 & .073 \\
.910 & .124 & .153 & .143 & .117 & .077 \\
.885 & .128 & .100 & .113 & .092 & .086 \\
.143 & .136 & .928 & -.04 & .171 & .063 \\
.126 & .106 & .941 &. .01 & .166 & .085 \\
.114 & .081 & .932 &. .01 & .173 & .087 \\
.184 & .053 & .821 & .005 & .009 & .036 \\
.135 & .066 & .896 & .034 & .056 &. .02 \\
.140 & .165 & .188 & .026 & .941 & .046 \\
.177 & .205 & .167 & .007 & .924 & .043 \\
.161 & .139 & .164 & .045 & .921 & .026 \\
\hline & & & & &
\end{tabular}

Muslim retail entrepreneurship resilience model is compiled which can be explained in Figure 1

From the results of the factor analysis, a 


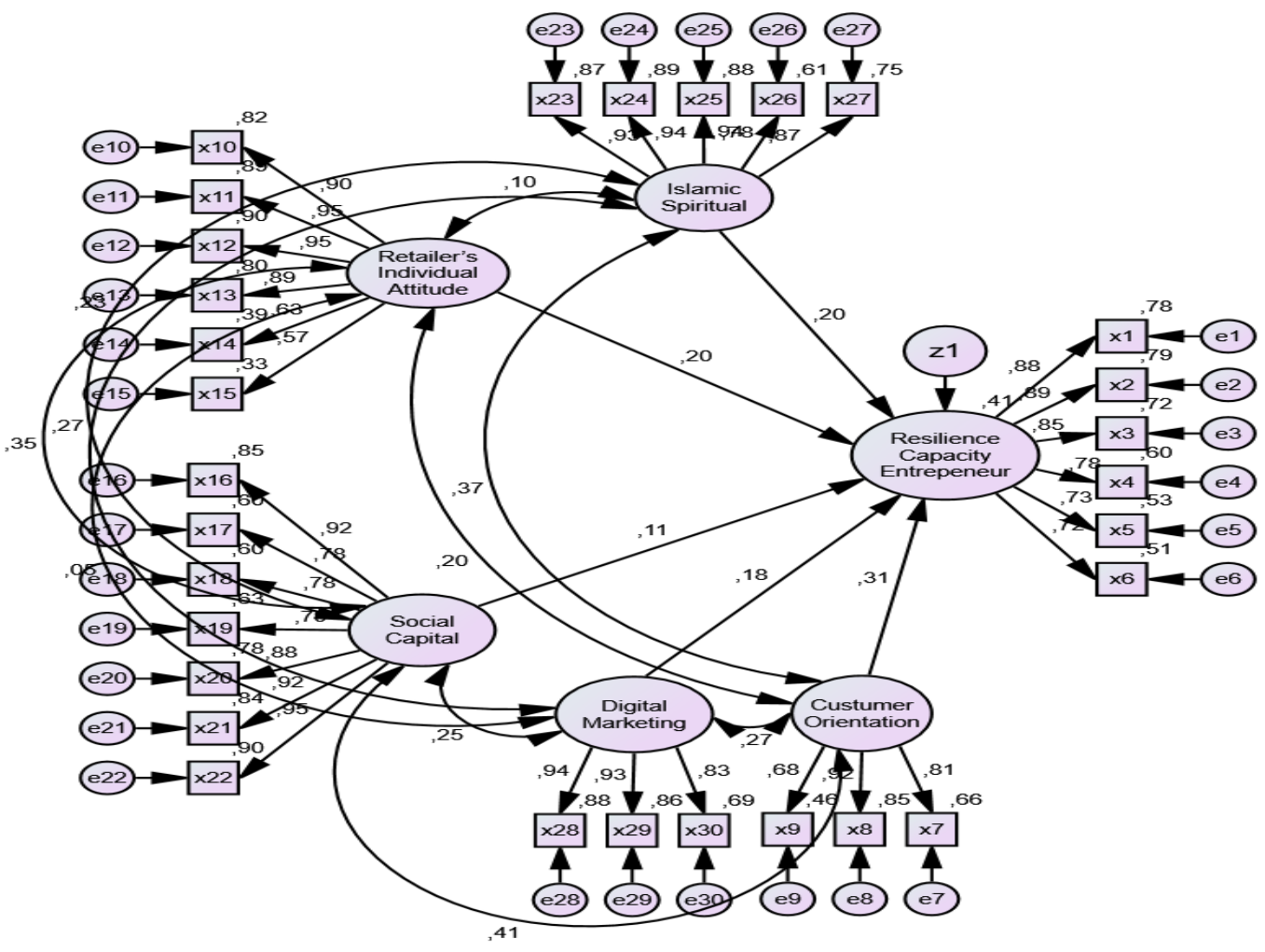

Table V the Result SEM

\begin{tabular}{|ll|rrr|}
\hline & & Est & C.R. & P. \\
\hline Resilience_Capacity_Entrepeneur & Social_Capital &, 1079 & 1,4518 &, 1465 \\
Resilience_Capacity_Entrepeneur & Digital_Marketing &, 1564 & 2,4610 &, 0138 \\
Resilience_Capacity_Entrepeneur & Islamic_Spiritual &, 1934 & 2,6310 &, 0085 \\
Resilience_Capacity_Entrepeneur & Retailer's_Individual_Attitude &, 2581 & 2,5950 &, 0094 \\
Resilience_Capacity_Entrepeneur & Custumer_Orientation &, 3126 & 3,6565 & $* * *$ \\
Goodness of Fit & Critical Value & & & \\
$\chi^{2}$ & & & \\
p & - & 216,34624 & \\
CMIN/df & $\geq 0,05$ &, 12984 & Good \\
RMSEA & $\leq 2,00$ & 1,11519 & Good \\
CFI & $\leq 0,05$ &, 02692 & Good \\
NFI & $\geq 0,95$ &, 99295 & Good
\end{tabular}




\begin{tabular}{|c|c|c|c|}
\hline & & Est & C.R. \\
\hline TLI & $\geq 0,95$ & ,99160 & Good \\
\hline GFI & $\geq 0,90$ & ,89112 & Marginal \\
\hline AGFI & $\geq 0,90$ & ,85801 & Marginal \\
\hline
\end{tabular}

Catatan: $\chi^{2}=$ chi square, $\mathrm{p}=$ probability, $\mathrm{CMIN} / \mathrm{df}=$ the minimum sample discrepancy function/degree of freedom, RMSEA = Root Mean Square Error of Approximation; NFI=Normed Fit Index; CFI=Comparative Fit Index; TLI=Tucker Lewis Index , GFI = Goodness of Fit Index; AGFI = Adjusted Goodness of Fit Index.

Figure I shows that the estimated model and standardized path coefficient estimates show good bias for testing the hypothesized paths. Statistically it shows an adequate fit with the data. The statistical results showed adequate compatibility with data $\chi^{2}=216.34624, p=$, 12984, CMIN / df $=1.11519, \mathrm{NFI}=, 93636$, $\mathrm{TLI}=$, 99160, CFI $=0.9931, \mathrm{GFI}=, 89112$, AGFI $=$, 85801, RMSEA $=$, 02692. The results for the structural path estimates show: (1) Customer Orientation can significantly increase the entrepreneur's resilience capacity $(\beta=, 31150, t=3.6565, p<0.001)$; (2) Islamic spiritual can significantly increase the entrepreneur's resilience capacity $(\beta=, 19583$, $\mathrm{t}=2.6310, \quad \mathrm{p} \quad<0.001)$;

Retailer's_Individual_Attitude significantly increase the entrepreneur's resilience capacity $(\beta=, 19522, \mathrm{t}=2.5950, \mathrm{p}$ $<0.001)$; (4) Digital_Marketing can significantly increase Entrepreneur Resilience Capacity $(\beta=, 18068, t=2.4610, p<0.001)$ and (5) Social_Capital can not significantly increase Entrepreneur Resilience Capacity ( $\beta$ $=, 11470, \mathrm{t}=1,4518, \mathrm{p}>0.05)$.

\section{Relationship between Customer Orientation and Resilience Capacity Entrepreneurs}

Customers are constituents for whom the product is produced, or services are provided by the entrepreneur. No business firm can survive, ignoring customer interests. In this case, Allah says "And $\mathrm{O}$ my people! Give only size and weight, or hold off the things people should. Do not commit evil on the ground with the intention of doing damage" (Quran, 11:85). Given the importance of customers, sharia entrepreneurs must develop business processes (core processes and supporting processes) in such a way that sufficient value is conveyed to customers, because; customers feel satisfied when their expectations regarding a service or product have been met or exceeded (Hoque et al., 2014). For this reason, Islam permits generating only reasonable profits (Mohammad Ather et al., 2011). Indeed, profit is a gift from the entrepreneur for taking the initiative and risk to set up a business enterprise. Undoubtedly, one must benefit through customer satisfaction; on the contrary; business firms will not be able to survive.

Customer satisfaction depends not only on product quality and performance but also on how customers are treated and how services are provided. Entrepreneurs must not promise any features or value in a product or service that they will not be able to provide to customers. Allah says "O you who believe! Fulfill the obligations "(Al-Quran, 5: 1). The Prophet (SAW) declared "Muslims are bound by their provisions" (Abu Da'ud). The Prophet 
(PBUH) condemned the breaking of promises as a mark or trait of a hypocrite. If he promises, he breaks it, and if he makes a pact, he is cheating (Bukhari). Customer orientation is defined as the capacity to understand and adapt proactively to changes in the needs and desires of demand in terms of the variety and level of services offered and sales capability defined as the ability of retailers to generate sales is considered the key to coping with the impact of the crisis (Pearson et al. al., 2011). Martinelli et al., (2019) argue that retail businesses exhibit resilience capacities capable of detecting and responding to changing consumer needs, and consequently adapting commercial offerings to the demands of communities affected by devastating natural disasters. While it may seem intuitive, it emphasizes the closeness of small businesses to their customer base. Hence, a more significant commitment to changing the needs and wants of customer demand takes a significant role.

Liu et al., (2012) study prove that retailers position themselves to serve crisis-hit communities, guarantee continuity in service at the expense of profits, are supported by clients and their increased loyalty. The role played by small retail business behaviour after the crisis and its ability to respond to change emerged as a vital tool in long-term recovery. This proves that customer orientation can increase the resilience capacity of retail entrepreneurs in times of crisis.

\section{Relationship between Islamic Spiritual and Resilience Capacity Entrepreneurs}

Islam views Spirituality as an act for the fundamental purpose of life. For example, the purpose of a Muslim's life is to worship Allah (Qur'an, 51:56). Nasr (1987) defines Islamic Spirituality as the presence of a relationship with Allah that affects an individual's selfesteem, sense of meaning and relationship with others and nature. The quality of Spirituality is based on Islamic teachings which consist of beliefs, rituals, daily behaviour and knowledge of obedience to a set of Islamic rituals and becoming closer to Allah and finding personal value (Khodayarifard et al., 2013). Mohsen (2007) defines Islamic Spirituality as taqwa. According to taqwa, it means avoiding Allah's punishment by doing what $\mathrm{He}$ commands and abstaining from doing what is forbidden. Islam, as a religion, encourages people to become entrepreneurs (Faizal et al., 2013). The Qur'an and the Hadith of the Prophet Muhammad SAW are the primary sources of the principles and rules of entrepreneurship and business. Entrepreneurship and company have a special place in Islam as a religion. Entrepreneurship and business in Islam are usually based on the following principles: entrepreneurship and business are an integral part of this religion; success is measured not only by the end result but also by the way in which it is achieved; Islam encourages people to get into business; business activities are part of worship or 'good deeds'; The guiding principles of entrepreneurship and business are based strictly on the Koran and Hadith, and ethics and social responsibility are based on the example of Muhammad SAW (Gümüsay, 2015; Ullah et al., 2013).

Successful entrepreneurs believe in their abilities and skills, and based on this, they firmly believe that they will succeed in their business initiatives and activities. Allah S.W.T promises that such people will be under His protection - "Allah is the protector of those who believes: from the depths of darkness $\mathrm{He}$ leads them out into the light" (Qur'an, 2: 257). 
Hassan \& Hippler, (2014) noted that in Islamic entrepreneurship and business, "success is measured not only by personal financial success but also by how well religious goals are achieved, which can reward entrepreneurs in the hereafter". In this regard, Allah S.W.T said: "There are people who say: 'O our Lord! Give us (Your gifts) in this world! 'but they will have no share in the afterlife. And some people say: 'Oh my God! Give us goodness in this world and goodness in the hereafter and protect us from the torment on fire! "They will be given what they have obtained, and God is fast in calculating" (AlQur'an, 2: 200-202). The results of the study (Mubarak et al., 2014) show that the characteristics of spiritual practice affect the motivation of natural entrepreneurs to build self-confidence and self-determination, uphold the principles of morality and help responsible management that will lead to success in their business.

Meanwhile, the study of Grine et al., (2015) found that the main source of Islamic Spirituality is the elements that entrepreneurs will personally practice including their basic knowledge, namely the knowledge they are pursuing, the basic knowledge they hold from the Qur'an, prayer (do'a), trusting God, paying zakat, and giving thanks (shukr) to God and people, God's dhikr (dhikr) and forgiveness lead effectively to the truth. Achour et al., (2014) noted that reciting the Qur'an and understanding its meaning supports and at the same time motivates Muslims to tackle life's problems effectively and further improve their quality of decision making. The study of Rehan et al., (2019) found that there is a stronger attitude towards entrepreneurship who regularly participates in religious practices.

The results of Abdullah's study (2013) show that the conditions of absolute values are configured based on mu'amalah needs which are focused on Islam and the reality of human needs today. Islam rewards business people for appearing alive by maximizing all the resources given within the scope justified to bring benefit to humanity. Besides that, it also serves to activate the potential that exists in entrepreneurs to continue to be tough and competitive. It can be concluded that spiritual Islamic can increase the resilience capacity of Muslim entrepreneurs.

\section{Relationship between the Retailer's Individual Attitude and Resilience Capacity Entrepreneur}

The resilience of a business is closely related to the strength of individual entrepreneurs (Teece, 2012). While personal resilience is related to abilities that are directly related to the company and professional profile of the entrepreneur, so it is essential the role played by the individual entrepreneur's resilience / himself and by his / her abilities and personal attitude when responding to unexpected events. Likewise, other research shows how it is possible to adapt to changing environments and unforeseen circumstances through selfcontrol and self-efficacy is an individual's belief in his ability to succeed in doing something. Moreover, individual resilience is enhanced by integrating previous experiences with knowledge, skills and skills to help them face an uncertain future with a positive attitude, creativity and optimism, and by relying on their resources (Ayala \& Manzano, 2014). Refers to the capacity of the entrepreneur to maintain a positive attitude in difficult 
circumstances, situations where there is significant uncertainty about the outcome. The ability of entrepreneurs to learn from mistakes and see them as opportunities rather than failures (Schneider, 2001). Also, difficulties and uncertainties are overcome by developing resilience. Therefore, entrepreneurs need a resilient attitude and effective behaviour to deal with uncertainty (Bullough \& Renko, 2013). Successful entrepreneurs have a well-established survival instinct because they have a positive attitude towards risk (Hedner et al., 2011) who remain positive in the face of setbacks and sometimes view failure as an opportunity to renew or start over (Hayward et al., 2010). There are two categories of successful Islamic entrepreneurial attitudes, namely attitudes toward oneself and attitudes toward customers. Attitude towards oneself is honest, sincere, disciplined, systematic, willing to work overtime, naturally gifted, likes the business world, is not selfish and is in accordance with Allah's commands. Whereas the attitude towards customers is generous with a smile, willing to listen to customer criticism, not nagging, using kind words, compromising with customers, knowing regularly and the main customer, giving choices to clients, not practising favoritism, choosing love, always say thank you, be patient with customers (Yazilmiwati Yaacob \& Ilhaamie Abdul Ghani Azmi, 2010). It can be concluded that the Retailer's Individual Attitude can increase the resilience capacity of Muslim entrepreneurs.

\section{Digital Marketing Relationship with Resilience Capacity Entrepreneurs}

The state of crisis caused by the COVID-19 pandemic has had a dramatic effect on all global economic activities in every region of the world (Bofinger et al., 2020). To flatten the Covid 19 infection rate curve, several countries around the world have imposed widespread restrictions (for example, lockdowns, quarantines and closings of physical shops and businesses) to protect the functioning of health care systems (Michie, 2020). This closure had a substantial direct impact on economic activity in almost every sector. For example, activities that involve direct contact between consumers and service providers have been affected by restrictions on movement and social distance (Giritli Nygren \& Olofsson, 2020). Today, to survive and thrive, companies must include digital channels as part of their marketing strategies and learn how to connect with their customers across various digital platforms to engage them through unique experiences and to create lasting, profitable relationships (Edmiston, 2015). This condition causes companies, including retail businesses, to review their marketing strategies by using digital marketing to maintain effective communication with consumers. According to Oklander et al., (2018) to develop an effective marketing strategy at this time, it is necessary to develop technological innovations related to digital marketing, especially managing relationships with consumers. Digital marketing is a practical and innovative marketing approach during a pandemic. Referring to creation, Gümüsay, (2015) argues that Islam encourages innovation utilizing consensus and analogy, which are essential pillars of Islamic teachings.

Regarding the dynamism and innovation of entrepreneurs, Allah says which means to say, "We do not change people's conditions until they do not change conditions within themselves" (Al-Qur'an 13:11). The fact is there is no room for the lazy and idle brains of 
Islam. According to the teachings of Islam, man can have nothing but what he stands for (Al-Qur'an 53:39). It can be concluded that digital marketing can increase the resilience capacity of Muslim entrepreneurs.

The relationship between Social Capital and Resilience Capacity Entrepreneur

Social capital is broadly defined as "the networks and resources available to people through their connections with others" (Aldrich \& Meyer, 2015) which connections offer information, enable the trust to emerge, and provide access to resources. In the entrepreneurial literature, social capital is considered as a contextual complement and a key asset for small companies (Lee \& Jones, 2015). Through social capital, entrepreneurs can identify opportunities and mobilize resources (Adler \& Kwon, 2002). Social capital is considered as a personal network of entrepreneurs, based on family members, friends, and business contacts who have direct contact with connected entrepreneurs and indirect relationships between them (Dubini \& Aldrich, 1991). Social capital has been considered an essential part of organizational resilience (Lengnick-Hall et al., 2011). In this regard, Powley, (2009) argues that relational redundancy plays an essential role in supporting the activation of the disruptive relational network of events. Therefore, direct and inexpensive access to network-wide resources can be considered as a contextual resilience capability (Lengnick-Hall et al., 2011). This is a critical element in creating contextual conditions that support the development of entrepreneurial resilience to adverse events and positively affect the recovery time and process, especially for the small number of independent entrepreneurs
(Asgary et al., 2012). Resources and capabilities secured by socially linked networks expand the range of possible actions, thereby stimulating entrepreneurial innovation and resilience (Lengnick-Hall \& Beck, 2005).

Sarif's study (2015) explores the effect of ta'awun-based social capital (the concept of cooperation) in the resilience of small business enterprises. Ta'awun uses universal solidarity (ukhuwwah) through mutual cooperation between stakeholders in providing financial and non-financial capital in building business resilience for sustainable performance. In general, ta'awun is defined as mutual cooperation or mutual cooperation for good. From a sharia perspective, ta'awun is prohibited from being used for illegal, criminal and dangerous activities. This is in line with the primary goal of Islam, which emphasizes the implementation of duties as servants of Allah. The results of a study by Sarif, (2015) show that social capital based on ta'awun allows business resilience for small businesses. It can be concluded that social capital can increase the resilience capacity of Muslim entrepreneurs. However, in this study, social capital affects the resilience capacity of Muslim entrepreneurs, but it is not significant. Thus, social capital can increase the resilience capacity of Muslim entrepreneurs. However, this study shows that social capital affects the resilience capacity of Muslim entrepreneurs, but not significantly. This shows that Muslim entrepreneurs need to increase their ability to build networks, both through sales and distributors, government, banks and financial institutions, merchant associations, and other retail traders. Because, in theory, social capital can increase the capacity of entrepreneurial resilience. 


\section{Conclusion}

From the results of the discussion, it can be concluded that resilience capacity entrepreneurship, customer orientation, retailer's attitude, social capital, Islamic spiritual and digital marketing are the factors that cause Muslim retail entrepreneurs to have the ability to survive in a crisis. The model test shows that customer orientation, retailer's attitude, Islamic spiritual and digital marketing have a significant effect on the resilience capacity of retail Muslim entrepreneurs. In contrast, social capital has an impact on but not substantial. Therefore, it is proven that Muslim entrepreneurs have the capability of customer orientation, personal attitude towards resilience, Islamic Spirituality, digital marketing is the driving forces for the recovery of Muslim retail entrepreneurs. However, the role of social capital, such as the role of institutions and society, the role of government, and the role of associations or other entrepreneurs, has not been able to demonstrate the resilience capacity of retail entrepreneurs. For that, we need encouragement, support, coaching and support to empower retail business businesses.

\section{Recommendation}

For future research, it is necessary to reexamine the relationship between social capital and resilience capacity of Muslim entrepreneurs, because, in theory, social capital affects the resilience capacity of entrepreneurs (Aldrich \& Meyer, 2015; Lee \& Jones, 2015; Lengnick-Hall et al., 2011). In Islam, the meaning of social capital to achieve prosperity is part of the Islamic social welfare system. In other words, Islamic social capital is a network or networking that helps create linkages which in turn motivate entrepreneurs to play a role in the development process. Therefore, the concept of ta'awun-based social capital has added a new dimension to the dialogue on developing successful entrepreneurship from an Islamic perspective.

\section{References}

Abdullah, S. Bin. (2013). The Characteristics of Successful Entrepreneurs from Islamic Perspective. Journal of Islamic and Human Advanced Research, 3(6), 322-345. https://doi.org/10.2298/eka0462025p

Abdullah, S. A. C., \& Sahad, M. N. (2016). Integrated marketing communication: a spiritual and an ethical Islamic perspective. 1(4).

Achour, M., Grine, F., Mohd Nor, M. R., \& MohdYusoff, M. Y. Z. (2014). Measuring Religiosity and Its Effects on Personal Well-Being: A Case Study of Muslim Female Academicians in Malaysia. Journal of Religion and Health, 54(3), 984-997. https://doi.org/10.1007/s10943-0149852-0

Adler, P. S., \& Kwon, S. W. (2002). Social capital: Prospects for a new concept. Academy of Management Review, 27(1), $17-40$

https://doi.org/10.5465/AMR.2002.59 22314

Akgün, A. E., \& Keskin, H. (2014). Organizational resilience capacity and firm product innovativeness and performance. International Journal of Production Research, 52(23), 6918-6937. https://doi.org/10.1080/00207543.201 4.910624

Al-bantani, N. (2020). Utilization of Digital Marketing to Improve Sales Volume of 
MSME's Products. Journal of Digital Marketing and Halal Industry, 2(1), 29-42.

Aldrich, D. P., \& Meyer, M. A. (2015). Social Capital and Community Resilience. American Behavioral Scientist, 59(2), 254269.

https://doi.org/10.1177/000276421455 0299

Alves, J. C., Lok, T. C., Luo, Y., \& Hao, W. (2020). Crisis Management for Small Business during the COVID-19 Outbreak: Survival, Resilience and Renewal Strategies of Firms in Macau. Research Square, PREPRINT(June), 1-29. https://doi.org/10.21203/rs.3.rs34541/v1

Annalakshmi, N., \& Abeer, M. (2011). Islamic worldview, religious personality and resilience among Muslim adolescent students in India. Europe's Journal of Psychology, 7(4), 716-738. https://doi.org/10.5964/ejop.v7i4.161

Asgary, A., Anjum, M. I., \& Azimi, N. (2012). Disaster recovery and business continuity after the 2010 flood in Pakistan: Case of small businesses. International Journal of Disaster Risk Reduction, 2, 46-56. https://doi.org/10.1016/j.ijdrr.2012.08. 001

Ayala, J. C., \& Manzano, G. (2014). The resilience of the entrepreneur. Influence on the success of the business. A longitudinal analysis. Journal of Economic Psychology, 42, 126-135. https://doi.org/10.1016/j.joep.2014.02. 004

Bhamra, R., Dani, S., \& Burnard, K. (2011). Resilience: The concept, a literature review and future directions. International Journal of Production Research, 49(18),
5375-5393.

https://doi.org/10.1080/00207543.201 1.563826

Bofinger, P., Dullien, S., Felbermayr, G., Fuest, C., Hüther, M., Südekum, J., \& Weder di Mauro, B. (2020). Economic Implications of the Corona Crisis and Economic Policy Measures. Wirtschaftsdienst, 100(4), 259-265. https://doi.org/10.1007/s10273-0202628-0

Bojorges Moctezuma, N. P., \& Rajagopal, N. A. (2016). Role of digital marketing in driving business performance in emerging markets: an analytical framework. International Journal of Business Forecasting and Marketing Intelligence, 2(4), 291. https://doi.org/10.1504/ijbfmi.2016.10 000960

Branicki, L. J., Sullivan-Taylor, B., \& Livschitz, S. R. (2018). How entrepreneurial resilience generates resilient SMEs. International Journal of Entrepreneurial Behaviour and Research, 24(7), 12441263.

Brück, T., Llussá, F., \& Tavares, J. A. (2011). Entrepreneurship: The role of extreme events. European Journal of Political Economy, 27(SUPPL. 1), S78-S88. https://doi.org/10.1016/j.ejpoleco.2011 .08 .002

Bullough, A., \& Renko, M. (2013). Entrepreneurial resilience during challenging times. Business Horizons, 56(3), 343-350. https://doi.org/10.1016/j.bushor.2013. 01.001

Carmeli, A., Friedman, Y., \& Tishler, A. (2013). Cultivating a resilient top 
management team: The importance of relational connections and strategic decision comprehensiveness. Safety Science, 51(1), 148-159. https://doi.org/10.1016/j.ssci.2012.06.0 02

Dijk, A. M. (2020). How entrepreneur resilience impacts the utilization of innovation in dealing with adversities like the COVID-19 pandemic in the restaurant industry in the Netherlands . CC-BY-NC (pp. 1-11). Behavioural, Management and Social Sciences, University of Twente.

Druss, R. G., \& Douglas, C. J. (1988). Adaptive responses to illness and disability. Healthy denial. General Hospital Psychiatry, 10(3), 163-168. https://doi.org/10.1016/0163. 8343(88)90015-1

Dubini, P., \& Aldrich, H. (1991). Personal and extended networks are central to the entrepreneurial process. Journal of Business Venturing, 6(5), 305-313.

Edmiston, D. (2015). Strategic digital marketing. Journal of Engineering, Design and Technology, 24(1), 90-91. https://doi.org/10.1108/172605312112 74729

Faizal, P. R. M., Ridhwan, A. A. M., \& Kalsom, A. W. (2013). The Entrepreneurs Characteristic from alQuran and al-Hadis. International Journal of Trade, Economics and Finance, 4(4), 191-196.

https://doi.org/10.7763/ijtef.2013.v4.2 84

Giritli Nygren, K., \& Olofsson, A. (2020). Managing the Covid-19 pandemic through individual responsibility: the consequences of a world risk society and enhanced ethopolitics. Journal of Risk
Research, $\quad 0(0), \quad 1-5$. https://doi.org/10.1080/13669877.202 0.1756382

Grine, F., Fares, D., \& Meguellati, A. (2015). Islamic Spirituality and entrepreneurship: A case study of women entrepreneurs in Malaysia İslami maneviyat ve girişimcilik: Malezya' daki kadın girişimciler üzerine bir vaka incelemesi. The Journal of Happiness $\mathbb{E}$ Well-Being, 3(1), 41-56.

Gümüsay, A. A. (2015). Entrepreneurship from an Islamic Perspective. Journal of Business Ethics, 130(1), 199-208. https://doi.org/10.1007/s10551-0142223-7

Härting, R., Reichstein, C., Laemmle, P., \& Sprengel, A. (2019). Potentials of digital business models in the retail industry Empirical results from european experts. Procedia Computer Science, 159, 10531062.

https://doi.org/10.1016/j.procs.2019.09 .274

Hassan, M. K., \& Hippler, W. J. (2014). Entrepreneurship and Islam: An overview. Econ Journal Watch, 11(2), 170178.

https://doi.org/10.2139/ssrn.3263110

Hayward, M. L. A., Forster, W. R., Sarasvathy, S. D., \& Fredrickson, B. L. (2010). Beyond hubris: How highly confident entrepreneurs rebound to venture again. Journal of Business Venturing, 25(6), 569578.

https://doi.org/10.1016/j.jbusvent.2009 .03 .002

Hedner, T., Abouzeedan, A., \& Klofsten, M. (2011). Entrepreneurial resilience. Annals of Innovation Eु Entrepreneurship, 2(1), 7986. 
https://doi.org/10.3402/aie.v2i1.6002 Hoque, N., Mamun, A., \& Mohammad Ahshanul Mamun, A. (2014). Dynamics and traits of entrepreneurship: an Islamic approach. World Journal of Entrepreneurship, Management and Sustainable Development, 10(2), 128-142. https://doi.org/10.1108/wjemsd-042013-0027

Khodayarifard, M., Ghobari-Bonab, B., Shokoohi-Yekta, M., Faghihi, A. N., Beh-Pajooh, A., Afrooz, G.-A., Abedini, Y., \& Paknejad, M. (2013). Developing a Religiosity Scale for Iranian College Student. Procedia - Social and Behavioral Sciences, $\quad 82, \quad 432-435$. https://doi.org/10.1016/j.sbspro.2013.0 6.288

Korber, S., \& McNaughton, R. B. (2017). Resilience and entrepreneurship: a systematic literature review. International Journal of Entrepreneurial Behavior $\mathcal{E}$ Research, 34(1), 1-5.

Kuckertz, A., Brändle, L., Gaudig, A., Hinderer, S., Morales Reyes, C. A., Prochotta, A., Steinbrink, K. M., \& Berger, E. S. C. (2020). Startups in times of crisis - A rapid response to the COVID-19 pandemic. Journal of Business Venturing Insights, 13(April). https://doi.org/10.1016/j.jbvi.2020.e00 169

Lee, R., \& Jones, O. (2015). Entrepreneurial social capital research: resolving the structure and agency dualism. International Journal of Entrepreneurial Behavior Eु Research, 21(3), 338-363.

Lengnick-Hall, C. A., \& Beck, T. E. (2005). Adaptive fit versus robust transformation: How organizations respond to environmental change. Journal of Management, 31(5), 738-757. https://doi.org/10.1177/014920630527 9367

Lengnick-Hall, C. A., Beck, T. E., \& LengnickHall, M. L. (2011). Developing a capacity for organizational resilience through strategic human resource management. Human Resource Management Review, 21(3), 243-255. https://doi.org/10.1016/j.hrmr.2010.07 .001

Linnenluecke, M. K. (2017). Resilience in Business and Management Research: A Review of Influential Publications and a Research Agenda. International Journal of Management Reviews, 19(1), 4-30. https://doi.org/10.1111/ijmr.12076

Liu, C., Black, W. C., Lawrence, F. C., \& Garrison, M. E. B. (2012). Post-disaster coping and recovery: The role of perceived changes in the retail facilities. Journal of Business Research, 65(5), 641647.

https://doi.org/10.1016/j.jbusres.2011. 03.004

London, M. (1993). Relationships between career motivation, empowerment and support for career development. Journal of Occupational and Organizational Psychology, 66(1), 55-69. https://doi.org/10.1111/j.2044-

8325.1993.tb00516.x

Luthans, F., Vogelgesang, G. R., \& Lester, P. B. (2006). Developing the Psychological Capital of Resiliency. Human Resource Development Review, 5(1), 25-44. https://doi.org/10.1177/153448430528 5335

Machmud, A., \& Hidayat, Y. M. (2020). 
Characteristics of Islamic entrepreneurship and the business success of SMEs in Indonesia. Journal of Entrepreneurship Education, 23(2), 1-16.

Martinelli, E., De Canio, F., \& Tagliazucchi, G. (2019). Bouncing back from a sudden-onset extreme event: exploring retail enterprises' resilience capacity. International Review of Retail, Distribution and Consumer Research, 29(5), 568-581. https://doi.org/10.1080/09593969.201 9.1664614

Martinelli, E., \& Tagliazucchi, G. (2019). Entrepreneurs' resilience to natural disasters: a survey in the retail sector. Italian Journal of Management, 37(1), 4361.

Michie, J. (2020). The covid-19 crisis-and the future of the economy and economics. International Review of Applied Economics, 34(3), 301-303. https://doi.org/10.1080/02692171.202 0.1756040

Nasr, S.H. (1987), Islamic Spirituality, Routledge and Kegan Paul, London

Mohammad Ather, S., Aktaruzzaman Khan, M., \& Hoque, N. (2011). Motivation as conceptualized in traditional and Islamic management. Humanomics, 27(2), 121137.

https://doi.org/10.1108/082886611111 35126

Mubarak, M. Z., Rahman, A. A., \& Yaacob, M. R. (2014). Spirituality in Islamic Entrepreneurship: Motivation and Achievements of Successful. Journal of Techno Social, 6(2), 27-36.

Mubarok, F. K. (2019). Optimalisasi Produk Qardhul Hasan dalam Memberdayakan Ekonomi Umat. Akuntabel, 16(1), 62-68. https://doi.org/10.29264/jakt.v16i1.463
8

Oklander, M., Oklander, T., Yashkina, O., Pedko, I., \& Chaikovska, M. (2018). Analysis of technological innovations in digital marketing. Eastern-European Journal of Enterprise Technologies, 5(3-95), 80-91. https://doi.org/10.15587/1729. 4061.2018.143956

Omri, W., Becuwe, A., \& Randerson, K. (2017). Unravelling the link between creativity and individual entrepreneurial behaviour: The moderating role of islamic work ethics. International Journal of Entrepreneurship and Small Business, 30(4), 567-589. https://doi.org/10.1504/IJESB.2017.08 2916

Pearson, M. M., Hickman, T. M., \& Lawrence, K. E. (2011). Retail recovery from natural disasters: New Orleans versus eight other United States disaster sites. International Review of Retail, Distribution and Consumer Research, 21(5), 415-444. https://doi.org/10.1080/09593969.201 1.619665

Powley, E. H. (2009). Reclaiming resilience and safety: Resilience activation in the critical period of crisis. Human Relations, 62(9),

1289-1326. https://doi.org/10.1177/001872670933 4881

Rehan, M. F., Block, J., \& Fisch, C. (2019). Entrepreneurship in Islamic communities: How do Islamic values and Islamic practices influence entrepreneurship intentions? Journal of Enterprising Communities, 13(5), 557-583. https://doi.org/10.1108/JEC-05-20190041

Rutter, M. (1987). Psychosocial resilience and protective mechanisms. American Journal 
of Orthopsychiatry, 57(3), 316-331.

Salleh, K., Ab Rahman, Z., Mohd Noor, A. ., Kashim, M., Long, S., Hasan, Z., \& Ridzuan, R. (2020). Resilience and patience (sabr) in Islamic view when observing the movement control (order MCO) during the covid 19 pandemic. International Journal of Psychosocial Rehabilitation, 24(01), 5485-5497.

Sarif, S. M. (2015). TA'AWUN-BASED SOCIAL CAPITAL AND BUSINESS RESILIENCE FOR SMALL BUSINESSES. South East Asia Journal of Contemporary Business, Economics and Law, 7(2), 24-34.

Schneider, S. L. (2001). In search of realistic optimism: Meaning, knowledge, and warm fuzziness. American Psychologist, $56(3)$, 250-263. https://doi.org/10.1037/0003. 066X.56.3.250

Seligman, M. E. P. (2011). Building resilience. Harvard Business Review, 89(4), 100-106. https://doi.org/10.7748/ns.26.32.16.s2 1

Shamsudin, A. S., Mohd Kassim, A. W., Hassan, M. G., \& Johari, N. A. (2010). Preliminary insights on the effect of Islamic Work Ethic on relationship marketing and customer satisfaction. The Journal of Human Resource and Adult Learning, 6(June 2010), 106-114.

Teece, D. J. (2012). Dynamic Capabilities: Routines versus Entrepreneurial Action. Journal of Management Studies, 49(8), 1395-1401.

https://doi.org/10.1111/j.1467-

6486.2012.01080.x

Thorgren, S., \& Williams, T. A. (2020). Staying alive during an unfolding crisis:
How SMEs ward off impending disaster. Journal of Business Venturing Insights, 14(July), e00187. https://doi.org/10.1016/j.jbvi.2020.e00 187

Tukamuhabwa, B. R., Stevenson, M., Busby, J., \& Zorzini, M. (2015). Supply chain resilience: Definition, review and theoretical foundations for further study. International Journal of Production Research, 53(18), 5592-5623. https://doi.org/10.1080/00207543.201 5.1037934

Ullah, M., Mahmud, T. B., \& Yousuf, F. (2013). Women Entrepreneurship: Islamic Perspective. European Journal of Business and Management, 1(1), 125-140.

Yazilmiwati Yaacob, \& Ilhaamie Abdul Ghani Azmi. (2010). To What Extent Do The Entrepreneur's Key Success Factor Influence The Muslim Entrepreneur From The Islamic Perspective? A Study on Muslim Beauty Entrepreneur's in Selangor. International Conference on Business and Economics (Icbe), 1-13. http://fekon.unand.ac.id/icbe/index.ph p?option $=$ com_content $\&$ view $=$ article $\&$ id $=56 \&$ Itemid $=66 \&$ limitstart $=1 \&$ lang $=$

Youssef, C. M., \& Luthans, F. (2007). Positive organizational behavior in the workplace: The impact of hope, optimism, and resilience. Journal of Management, 33(5), $774-800$

https://doi.org/10.1177/014920630730 5562 